\title{
Propiconazole Sensitivity in Populations of Geotrichum candidum, the Cause of Sour Rot of Peach and Nectarine, in California
}

\author{
Mohammad A. Yaghmour and Richard M. Bostock, Department of Plant Pathology, University of California, Davis 95616; \\ James E. Adaskaveg, Department of Plant Pathology and Microbiology, University of California, Riverside, CA 92521; and \\ Themis J. Michailides, Department of Plant Pathology, University of California, Kearney Agricultural Center, Parlier 93648
}

\begin{abstract}
Yaghmour, M. A., Bostock, R. M., Adaskaveg, J. E., and Michailides, T. J. 2012. Propiconazole sensitivity in populations of Geotrichum candidum, the cause of sour rot of peach and nectarine, in California. Plant Dis. 96:752-758.

The sour rot pathogen of peach (Prunus persica var. persica) and nectarine (P. persica var. nectarina) fruit, Geotrichum candidum, can cause significant postharvest losses in California fruit production. Harvested peach and nectarine fruit, treated with fungicide at the packinghouse but culled after inspection because of disease and defects, were collected for further assessment and pathogen isolation. The incidence of fruit with sour rot was $3.4 \pm 1.0$ to $26.1 \pm 2.3 \%$. Culled fruit that had been treated with postharvest fungicides from five different orchards had a significantly higher incidence of sour rot when compared with nontreated fruit. Since August 2006, propiconazole has been used as a postharvest treatment to protect peach and nectarine fruit against sour rot. The mean effective concentration that inhibits $50 \%$ of mycelial growth $\left(\mathrm{EC}_{50}\right)$ value of 57 isolates of $G$. candidum to propiconazole

lates from propiconazole-treated, diseased fruit collected from 2007 to 2009 had a mean $\mathrm{EC}_{50}$ value for mycelial growth of $0.378 \mu \mathrm{g} / \mathrm{ml}$, a fivefold shift in mean sensitivity. Propiconazole applied as either a protective or curative treatment significantly reduced disease severity and decay development in fruit inoculated with a propiconazole-sensitive isolate. The fungicide was significantly less effective when applied as a preventive or a curative application to fruit that were inoculated with a less-sensitive isolate of G. candidum. Under laboratory conditions, isolates of the pathogen less sensitive to propiconazole were stable over multiple transfers on fungicide-free medium. The potential for the development of $G$. candidum populations with reduced sensitivity to propiconazole and the increased risk of crop loss due to the practice of returning culled fruit to production orchards are discussed.
\end{abstract} collected before and during 2006 was $0.072 \mu \mathrm{g} / \mathrm{ml}$. However, 61 iso-
Sour rot, caused by Geotrichum candidum Link, has been reported to cause losses of fresh-market fruit such as peach (Prunus persica var. persica) and nectarine (P. persica var. nectarina) in California $(5,21,36)$, tomato $(6,15)$, and cantaloupe $(35)$. Other yeasts have also been associated with stone fruit decays when fruit are incubated at warm temperatures (26). In general, fungal pathogens such as Gloeosporium gloeosporioides and Geotrichum candidum are more prevalent in humid regions, whereas Monilinia fructicola, Rhizopus stolonifer, and Botrytis cinerea are considered more prevalent on fruit grown under semiarid conditions (15).

The use of fungicides mixed with wax emulsions during postharvest packaging of peach and nectarine can effectively control most of the major stone fruit decays such as brown rot, gray mold, and Rhizopus rot (17). Wells (36) reported that incidence of sour rot on fungicide/wax-treated fruit was greater than on nontreated fruit. This difference was explained by the protective effect of fungicides against other competing pathogens that cause fruit decay such as $M$. fructicola, $R$. stolonifer, and $B$. cinerea, and no effect against $G$. candidum. The fungicide fludioxonil, labeled as a "reduced-risk" pesticide by the Environmental Protection Agency (EPA), has been used in California on nectarine, peach, and plum since 1998. In artificially wound-inoculated fruit, this fungicide set a new standard in efficacy and safety as a treatment for control of postharvest decay $(16,17)$ but was not effective against sour rot.

Corresponding author: T. J. Michailides, E-mail: themis@uckac.edu

* The $e$-Xtra logo stands for "electronic extra" and indicates that a supplemental figure is included in the online edition and that Figure 1 appears in color online.

Accepted for publication 4 December 2011.

http://dx.doi.org/10.1094/PDIS-09-11-0796

(C) 2012 The American Phytopathological Society
Because fludioxonil was shown to be ineffective against sour rot, treatment options had not been forthcoming until 2006, when the fungicide propiconazole (Mentor 45WP; Syngenta Crop Protection, Greensboro, NC) received an emergency registration for sour rot management (3). Propiconazole in a different formulation (Tilt; Syngenta Crop Protection) has been and continues to be used as a preharvest treatment to control brown rot caused by M. fructicola. Resistance to propiconazole in $M$. fructicola has been reported in the southeastern United States $(10,31,42)$ but there are no reports of crop loss or reduced sensitivity of pathogen populations to pre- or postharvest use of propiconazole in California.

G. candidum is a soilborne organism (13) that can be deposited in soil dust on fruit and leaf surfaces of stone fruit trees in California (41). Packing lines can become contaminated with $G$. candidum from soil, plant debris, and infected fruit carried from the orchard in harvesting bins $(39,40)$. After harvest, fruit are transported to the packinghouse, where they are washed with chlorinated water and subsequently treated with fungicides and fruit coatings before being packed and handled for commercial distribution. In packinghouses in California, unmarketable peach and nectarine fruit (culled fruit) are hand sorted and graded from the conveyor belts following fungicide and fruit coating treatments. Low-grade fruit are used for juice, food processing, and animal feed. Occasionally, when demands for these secondary uses are low, fruit are dumped into landfills, returned to the edges of stone fruit production orchards or along the roads separating farms, or placed down the rows of production orchards (Fig. 1).

Because of the potential risk of fungicide resistance developing in populations of $G$. candidum, this study was undertaken with the following objectives: (i) to investigate the role of culled fruit in the epidemiology of the disease and as sources of isolates of G. candidum less sensitive to propiconazole and (ii) to assess the variation in sensitivity of $G$. candidum isolates obtained from culled fruit treated with propiconazole relative to a reference sensitive population. This information will be important in designing sour rot disease management strategies and for managing fungicide resistance in the field and packinghouse. 


\section{Materials and Methods}

Isolates of G. candidum and sources of inoculum. The isolates used in this study, their source, location, and year of collection are listed in Tables 1 and 2. An isolate was designated from an individual colony of $G$. candidum obtained in a dilution assay (see below) or from a single fruit lesion. Isolations were made from soil, leaf and fruit surfaces, packinghouse equipment, and decayed fruit.

To recover G. candidum from leaf surfaces, 25 leaves per sample were washed with $25 \mathrm{ml}$ of $0.005 \%$ Tween 20 (Sigma-Aldrich, St. Louis) in sterile, deionized water. To recover the pathogen from fruit surfaces, 30 mature fruit per sample were washed with $100 \mathrm{ml}$ of $0.005 \%$ Tween 20 in sterile deionized water. An aliquot of 0.2 $\mathrm{ml}$ of the washings from each sample were plated on a 9-cm petri dish containing potato dextrose agar (Microtech Scientific, Orange, CA) amended with novobiocin (Sigma-Aldrich) and fludioxonil (Syngenta Crop Protection) at 100 and $1 \mu \mathrm{g} / \mathrm{ml}$, respectively (PDA$\mathrm{NF}$ medium). The same medium was used for plating decayed tissues of fruit, fruit flies collected from decayed fruit in the field, and dilutions of suspended soil samples collected from peach and nectarine orchards.

Decaying fruit tissue was plated directly on PDA-NF. Fruit flies were collected from fruit dump sites, killed by freezing (27), and plated on PDA-NF. Soil samples from the top $2.5 \mathrm{~cm}$ were allowed to air dry for 5 days to a consistent weight before making soil dilutions with a spiral plater (Eddy Jet; Neutec Group Inc., New York, $\mathrm{NY})$. Soil (10 g) and $25 \mathrm{ml}$ of water were placed in 50-ml plastic tubes and shaken overnight on a horizontal shaker at $180 \mathrm{rpm}$. Soil suspensions were filtered through a double layer of cheese cloth and a 50- $\mu$ l aliquot of the filtered suspension was applied to $9-\mathrm{cm}$ plates containing PDA-NF media using the spiral plater.

For isolates collected from packinghouse equipment, Rodac plates (Microtech Scientific) with the PDA-NF media were used to sample the surfaces of the different stages of the packing lines of two packinghouses as follows: belt at the unloading area (area 1), brushes of the fungicide treatment bed (area 2), belt area after fungicide treatment bed (area 3), and belt area at the final pack site (area 4). All isolation plates were incubated at 23 to $25^{\circ} \mathrm{C}$ for $48 \mathrm{~h}$. Isolates of $G$. candidum were also collected from commercially sorted, decaying culled fruit, including fruit treated after harvest with propiconazole in a packinghouse. Isolations were made after incubating fruit at $20^{\circ} \mathrm{C}$ and $90 \%$ relative humidity for 5 days to stimulate fungal growth.
All isolates recovered from PDA-NF plates were allowed to grow at $25^{\circ} \mathrm{C}$ for 24 to $48 \mathrm{~h}$ and transferred to PDA. Isolates were identified as G. candidum based on morphology such as dichotomous and trichotomous apical hyphal branching and the presence of arthrospores. Stock cultures of these isolates were stored in water at $4^{\circ} \mathrm{C}$.

Incidence of sour rot and major postharvest diseases on culled fruit. Culled fruit collected from a packinghouse representing four distinct lots or orchards were obtained in 2007 and 2008 Fruit were collected immediately after emerging from the fungicide and fruit-coating application section of the packing line. The collected fruit were placed in clean plastic liners in cardboard boxes (two layers per box) and were incubated at $20^{\circ} \mathrm{C}$ and $90 \%$ humidity for 5 to 6 days. The incidence of fruit with sour rot and other postharvest diseases was recorded as the percentage of total fruit evaluated.

Table 1. Isolates of Geotrichum candidum used to determine the sensitivity to propiconazole of the reference population ${ }^{\mathrm{a}}$

\begin{tabular}{lcll}
\hline Source & $\begin{array}{c}\text { Number of } \\
\text { isolates }\end{array}$ & $\begin{array}{c}\text { County } \\
\text { of origin }\end{array}$ & \multicolumn{1}{c}{$\begin{array}{c}\text { Year } \\
\text { collected }\end{array}$} \\
\hline Nectarine, leaf surface & 7 & Kings, Tulare & 2006 \\
Peach, leaf surface & 3 & Fresno, Tulare & 2005,2006 \\
Nectarine, fruit surface & 4 & Tulare & 2006 \\
Nectarine, decayed fruit & 25 & Kings, Tulare & 2005,2006 \\
Peach, decayed fruit & 5 & Fresno, Tulare & 2005,2006 \\
Tomato, decayed fruit & 2 & Tulare & $\ldots$ \\
Packinghouse & 4 & Tulare & 2006 \\
Insect & 1 & Tulare & 2006 \\
Soil & 6 & Kings, Tulare & 2004,2007 \\
Total & 57 & $\ldots$ & $\ldots$ \\
\hline
\end{tabular}

${ }^{a}$ Isolates were collected from different substrates and locations from stone fruit orchards in California from 2004 to 2007.

Table 2. Isolates of Geotrichum candidum used to determine the sensitivity to propiconazole of the exposed population ${ }^{\mathrm{a}}$

\begin{tabular}{lcll}
\hline Source & $\begin{array}{c}\text { Number } \\
\text { of isolates }\end{array}$ & $\begin{array}{c}\text { County of } \\
\text { origin }\end{array}$ & $\begin{array}{c}\text { Year } \\
\text { collected }\end{array}$ \\
\hline Decayed culled fruit & 52 & Fresno & 2007,2008 \\
Decayed commercial fruit & 9 & Tulare & 2009 \\
Total & 61 & $\ldots$ & $\ldots$ \\
\hline
\end{tabular}

a Isolates were collected from decayed culled and commercial fruit from 2007 to 2009.
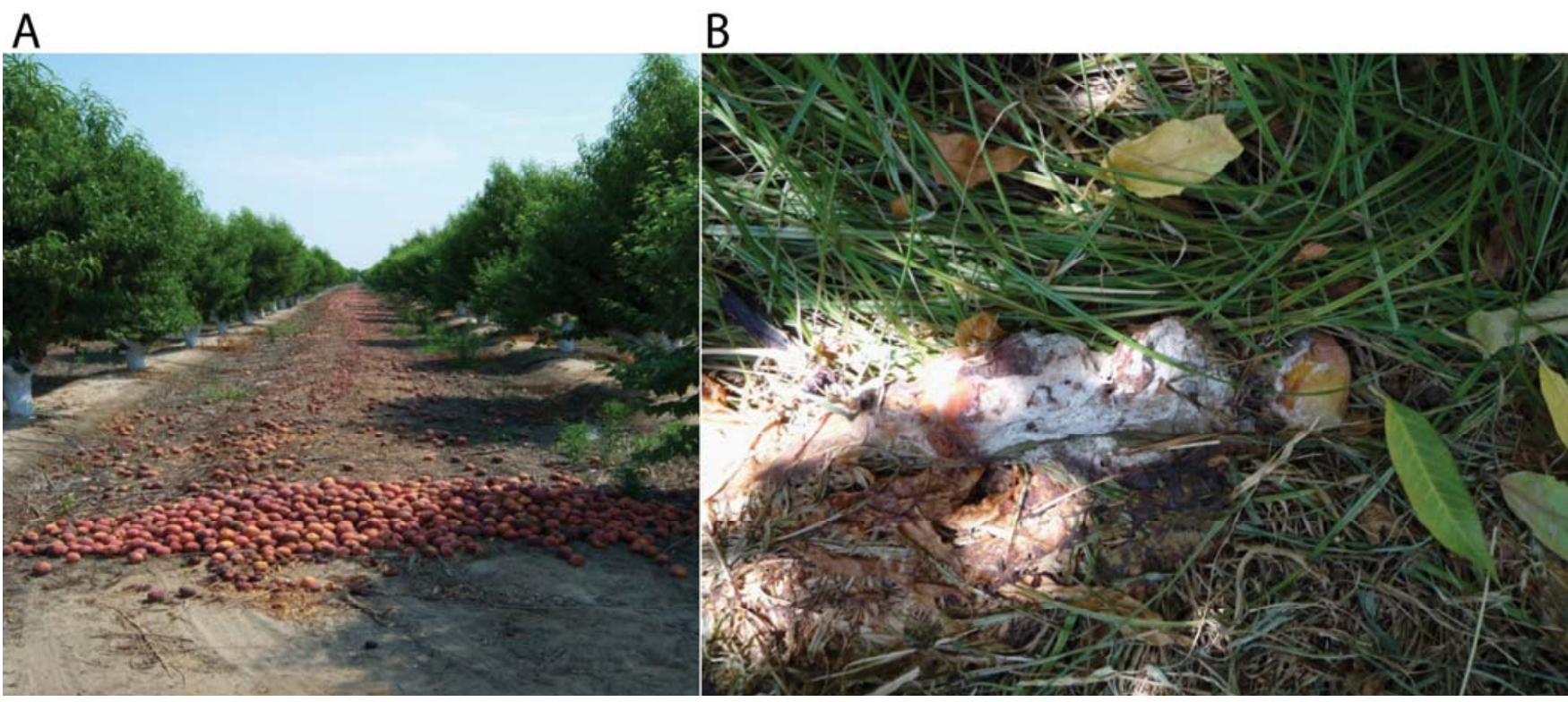

Fig. 1. A, Culled peach and nectarine fruit disposed between rows of a harvested stone fruit orchard, and B, sporulation of Geotrichum candidum on fruit in an irrigation trench of an orchard. 
In 2007, fruit were collected from five orchards before postharvest treatments (i.e., chlorinated wash, water rinse, fruit coating, and fungicide). Culled fruit of the same five orchards were collected at the packinghouse immediately after the fungicide and fruit-coating application. Fruit collected before or after postharvest treatments were incubated as described above and incidence of fruit with sour rot was recorded as the percentage of total number of fruit evaluated.

In vitro sensitivity of $G$. candidum to propiconazole. Sensitivity of mycelial growth of G. candidum to propiconazole was assessed for reference isolates collected before 2006 (before the registration of propiconazole as a postharvest treatment) and isolates collected from 2007 to 2009. Isolates were retrieved from stock spore suspensions and allowed to grow on PDA for $48 \mathrm{~h}$. A cube ( 3 by 3 by $3 \mathrm{~mm}$ ) of the culture was transferred to a fresh 9 $\mathrm{cm}$ PDA plate and rubbed across the surface of the plate. After 5 days at $25^{\circ} \mathrm{C}$, mycelial disks $(5 \mathrm{~mm}$ in diameter) were removed from the margins of the colony and transferred to PDA amended with propiconazole at $0.015,0.03,0.06$, or $0.125 \mu \mathrm{g} / \mathrm{ml}$ for the reference population and $0.125,0.250,0.5$, or $1.0 \mu \mathrm{g} / \mathrm{ml}$ for the exposed population. Propiconazole (Tilt; Syngenta Crop Protection) was added to molten $\left(50\right.$ to $\left.55^{\circ} \mathrm{C}\right) \mathrm{PDA}$. Petri plates without the fungicide amendment were used as controls. For each isolate, four replicate plates per concentration were used. The radial growth of each isolate after 3 days of incubation at $25^{\circ} \mathrm{C}$ in the dark was measured in two perpendicular directions, with the original mycelial plug diameter $(5 \mathrm{~mm})$ subtracted from this measurement. Fungicide sensitivity and effective concentration that inhibits $50 \%$ of mycelial growth $\left(\mathrm{EC}_{50}\right)$ was calculated as described by Wong and Midland (37) and Wong and Wilcox (38). Relative growth $(\mathrm{RG})$ for each isolate was calculated as the radial growth at a fungicide concentration divided by the radial growth of the fungus in control plates. For each isolate, a linear regression of the RG values versus the logarithm of fungicide concentrations was performed.

Stability of isolates less sensitive to propiconazole. To determine stability of isolates less sensitive to propiconazole, five lesssensitive and six sensitive isolates were compared after 10 sequential transfers onto fungicide-free PDA. Fungicide sensitivity was based on the mycelial growth test, as described earlier. A mycelial plug (5 mm in diameter) of each isolate was transferred to fungicide-free PDA every 7 days. After 10 transfers, propiconazolesensitive and propiconazole-less-sensitive isolates were transferred to propiconazole-amended and nonamended plates and $\mathrm{EC}_{50}$ values were determined as described above. Values were then statistically compared with the initial $\mathrm{EC}_{50}$ values determined for these isolates. This experiment was performed twice.

Fruit inoculation studies. A propiconazole-sensitive isolate (number 47) and a less-sensitive isolate (AB12) of G. candidum were used to inoculate peach and nectarine fruit. The sensitive isolate was collected in 2004 from soil of a nectarine ('Summer Fire') orchard in Tulare County, CA with a history of sour rot. The less sensitive (exposed) isolate was isolated from a nectarine fruit ('Autumn Blaze') that had been treated with propiconazole in the packinghouse, with the fruit originating from packinghouse 1 (unpublished data). The $\mathrm{EC}_{50}$ for the sensitive isolate was $0.03 \mu \mathrm{g} / \mathrm{ml}$ and for the less-sensitive isolate was $0.47 \mu \mathrm{g} / \mathrm{ml}$. Pathogenicity of both isolates was confirmed on peach and nectarine.

Mature nectarine ('Summer Fire') and peach ('Ryan Sun') fruit were kept at 0.6 to $1.6^{\circ} \mathrm{C}$ for up to 4 weeks until use. Fruit were surface sterilized by dipping in $1.6 \%$ of commercial chlorine $(\mathrm{NaOCl}), 1.6 \%$ ethyl alcohol, and $0.005 \%$ Tween 20 for $4 \mathrm{~min}$. Fruit were wounded to a depth of $1 \mathrm{~mm}$ with a glass rod $(2 \mathrm{~mm}$ in diameter) and inoculated with $20 \mu \mathrm{l}$ of a suspension of $10^{6}$ spores $/ \mathrm{ml}$ of either isolate. Fruit were treated with propiconazole at $135 \mu \mathrm{g} / \mathrm{ml}$ before wounding and inoculation, or were treated 18 to $20 \mathrm{~h}$ after inoculation by dipping in the fungicide suspension for 30 s. Wound-inoculated fruit without the fungicide treatment were used as controls. Fruit were supported on a $10-\mathrm{mm}$-high plastic screen mesh in a plastic container $(31$ by 22 by $10 \mathrm{~cm}$ ) (Pioneer
Plastics, Dixon, KY). To maintain high humidity, $200 \mathrm{ml}$ of water was added to the bottom of each container and not in contact with the fruit. Fruit were incubated at $24 \pm 2{ }^{\circ} \mathrm{C}$ for 5 days. Lesion diameters were measured in two perpendicular directions, and values were averaged for each lesion. The experiment was performed twice.

Determination of a single discriminatory dose of propiconazole to monitor sensitivity shifts in G. candidum. The discriminatory dose was determined as described by Wong and Midland (37) and Putman et al. (29). For this, two discriminatory doses, 0.1 and $0.125 \mu \mathrm{g} / \mathrm{ml}$, were tested to differentiate between the reference and the exposed populations. $\log \mathrm{EC}_{50}$ values for propiconazole-reference and -exposed populations of $G$. candidum were regressed against calculated $R G$ values of each of 57 sensitive and 61 less-sensitive isolates at each discriminatory dose. The dose with the highest coefficient of determination $\left(r^{2}\right)$ was selected as a discriminatory dose (29).

Statistical analyses. $\mathrm{EC}_{50}$ values were calculated for individual isolates using a linear regression analysis. RG was calculated as radial growth at fungicide concentration/radial growth on the nonamended check plate. RG values were plotted against the log fungicide concentration and regression performed through the linear portion of the dose response. The $\log \mathrm{EC}_{50}$ was calculated based upon the $\mathrm{x}$-intercept corresponding to an RG value of 0.5 . Analysis of $\mathrm{EC}_{50}$ values from the two experiments was performed using the mixed model analysis (SAS ver. 9.1; SAS Institute, Cary, NC). The data sets from the two experiments were combined because the two experiments were not statistically different $(P>0.05)$.

For discriminatory dose analysis, $\log \mathrm{EC}_{50}$ values for propiconazole-reference and -exposed populations of $G$. candidum were regressed against calculated RG values of each isolate at each discriminatory dose tested. RG values were expressed as percentages. Coefficient of determination $\left(r^{2}\right)$ and significance were calculated for the relationship for each of the two discriminatory doses (SAS ver. 9.1; SAS Institute).

Lesion diameters from inoculation experiments were log transformed to meet the $\mathrm{W}$ value at or greater than 0.95 in the ShapiroWilk test for normality despite the fact that the $P$ value was significant $(P<0.05)$. This was done to meet the assumptions to analyze the data using a mixed model. Data were analyzed first in an exploratory statistical model by including all variables (fruit type, isolate sensitivity, fungicide treatment, and experiment). The reduced model then was designed based on results from the exploratory model, excluding insignificant variables from the analysis.

Fungicide stability data were analyzed using the General Linear Model by using the Proc GLM statement in SAS. The effects of experiment, transfer time (T0 and T10), or the interaction between experiment and transfer time were included in the analysis. Data were expressed as a mean $\mathrm{EC}_{50}$ of six sensitive isolates and five less-sensitive isolates. The $t$ test was used to separate means for the $\mathrm{EC}_{50}$ values at transfer times $\mathrm{T} 0$ and $\mathrm{T} 10$.

\section{Results}

Isolates of $\boldsymbol{G}$. candidum and sources of inoculum. In total, 57 isolates collected from different substrates were marked as reference isolates (i.e., no prior exposure to propiconazole; Table 1), whereas 61 isolates were marked as less sensitive and were collected from culled fruit or decaying commercial fruit treated with propiconazole. Fifty-two isolates were collected from decaying culled fruit with sour rot after fruit were incubated at $20^{\circ} \mathrm{C}$ and $90 \% \mathrm{RH}$ for 5 days. Nine more isolates were collected from decaying commercial fruit in 2009 (Table 2).

Incidence of sour rot and major postharvest diseases on culled fruit. The incidence of sour rot and other postharvest diseases in culled fruit from four fields are presented in Table 3. The percentage of fruit with sour rot ranged from $3.4 \pm 1.0$ to $26.1 \pm$ $2.3 \%$. Other frequently recorded diseases included brown rot, gray mold, and Rhizopus and Gilbertella fruit decays (Table 3). When culled fruit were collected from five different orchards and compared with decayed fruit lots before the fruit were treated with wax 
and fungicide, in all cases, the treated fruit had a significantly higher incidence of sour rot than the nontreated fruit $(P<0.05$; Supplementary Figure S1). Sour rot was detected on treated culled fruit from all five orchards, and the percentage of decayed fruit was 1.0 to $19.7 \%$. However, sour rot was detected only on untreated fruit from orchard 1, with a percentage of $0.5 \%$ of untreated fruit.

In vitro sensitivity of $\boldsymbol{G}$. candidum to propiconazole. The $\mathrm{EC}_{50}$ values for the effect of propiconazole on mycelial growth of 57 isolates of $G$. candidum collected before and during 2006 from different substrates were 0.013 to $0.444 \mu \mathrm{g} / \mathrm{ml}$. The calculated mean $\mathrm{EC}_{50}$ was $0.072 \mu \mathrm{g} / \mathrm{ml}$. Approximately $86 \%$ of the isolates had an $\mathrm{EC}_{50}<0.072 \mu \mathrm{g} / \mathrm{ml}$, whereas only $14 \%$ of the isolates in this population had an $\mathrm{EC}_{50}>0.125 \mu \mathrm{g} / \mathrm{ml}$. In contrast, the $\mathrm{EC}_{50}$ values for 61 isolates collected during 2007 to 2009 from decayed culled fruit and fruit that had been treated with the fungicide were 0.013 to $0.566 \mu \mathrm{g} / \mathrm{ml}$, with a mean of $0.378 \mu \mathrm{g} / \mathrm{ml}$. Approximately $10 \%$ of the isolates collected during 2007 to 2009 showed an $\mathrm{EC}_{50}$ $<0.06 \mu \mathrm{g} / \mathrm{ml}$, whereas $90 \%$ of these isolates had an $\mathrm{EC}_{50}>0.125$ $\mu \mathrm{g} / \mathrm{ml}$. The $\mathrm{EC}_{50}$ frequency distributions for all isolates are presented in Figure 2A.

The ability of propiconazole to inhibit mycelial growth by $90 \%$ $\left(\mathrm{EC}_{90}\right)$ was estimated by extrapolation, using the equations for calculating the $\mathrm{EC}_{50}$ values. In all, $86 \%$ of the reference population isolates had an $\mathrm{EC}_{90}<1 \mu \mathrm{g} / \mathrm{ml}$, whereas $91 \%$ had an $\mathrm{EC}_{90}<2$ $\mu \mathrm{g} / \mathrm{ml}$. On the other hand, of the isolates in the exposed population, approximately 90 and $85 \%$ had an $\mathrm{EC}_{90}>1 \mu \mathrm{g} / \mathrm{ml}$ and $>2 \mu \mathrm{g} / \mathrm{ml}$, respectively (Fig. 2B).

Stability of isolates less sensitive to propiconazole. The stability of propiconazole sensitivity in G. candidum following sequential, weekly transfers over a 10 -week period on propiconazole-free medium is shown in Table 4 . There were no significant changes in the sensitivity to propiconazole of either the sensitive or less-sensitive isolates during the course of the experiment. The five lesssensitive isolates remained less-sensitive and their $\mathrm{EC}_{50}$ values for propiconazole were 0.344 to $0.497 \mu \mathrm{g} / \mathrm{ml}$. The six sensitive isolates remained sensitive and their $\mathrm{EC}_{50}$ values for propiconazole were 0.022 to $0.052 \mu \mathrm{g} / \mathrm{ml}$.

Fruit inoculation studies. The effect of propiconazole on a sensitive isolate and a less-sensitive isolate of G. candidum in inoculated fruit was assessed. Both isolates were pathogenic on peach and nectarine fruit with or without a preinoculation treatment of propiconazole at $135 \mu \mathrm{g} / \mathrm{ml}$. The exploratory statistical model showed that there was a significant interaction between isolate and treatment $(P<0.0001)$ and there was a significant effect of isolate on lesion diameter $(P<0.0001)$. However, there was no significant effect $(P=1.0)$ of the fruit type, peach or nectarine, used for the experiments. In addition, there was no significant difference between the two experiments conducted $(P=0.54)$ or treatment of fruit before or after inoculation $(P=0.12)$. The reduced model was designed based on prior results from the exploratory model and, thus, results from experiments using nectarine and peach fruit were combined. When fruit were treated with propiconazole at $135 \mu \mathrm{g} / \mathrm{ml}$ before or after inoculation, the sensitive isolate caused significantly smaller decay lesions than those caused by the less-sensitive isolate (Fig. 3A and B).

Determination of a single discriminatory dose of propiconazole to monitor sensitivity shifts in $G$. candidum. The relationship between $\mathrm{RG}$ and $\log \mathrm{EC}_{50}$ at $0.1 \mu \mathrm{g} / \mathrm{ml}$ is presented in Figure 4. Based on regression analysis of $R G$ versus calculated $\log \mathrm{EC}_{50}$ values in both reference and exposed populations, $0.1 \mu \mathrm{g} / \mathrm{ml}$ was determined to be the most accurate propiconazole concentration for a single discriminatory dose to screen for sensitivity shifts between the reference and exposed populations examined in this study. The $r^{2}$ was higher with $0.1 \mu \mathrm{g} / \mathrm{ml}\left(r^{2}=0.91\right)$ as a discriminatory dose than with $0.125 \mu \mathrm{g} / \mathrm{ml}\left(r^{2}=0.83\right)$.
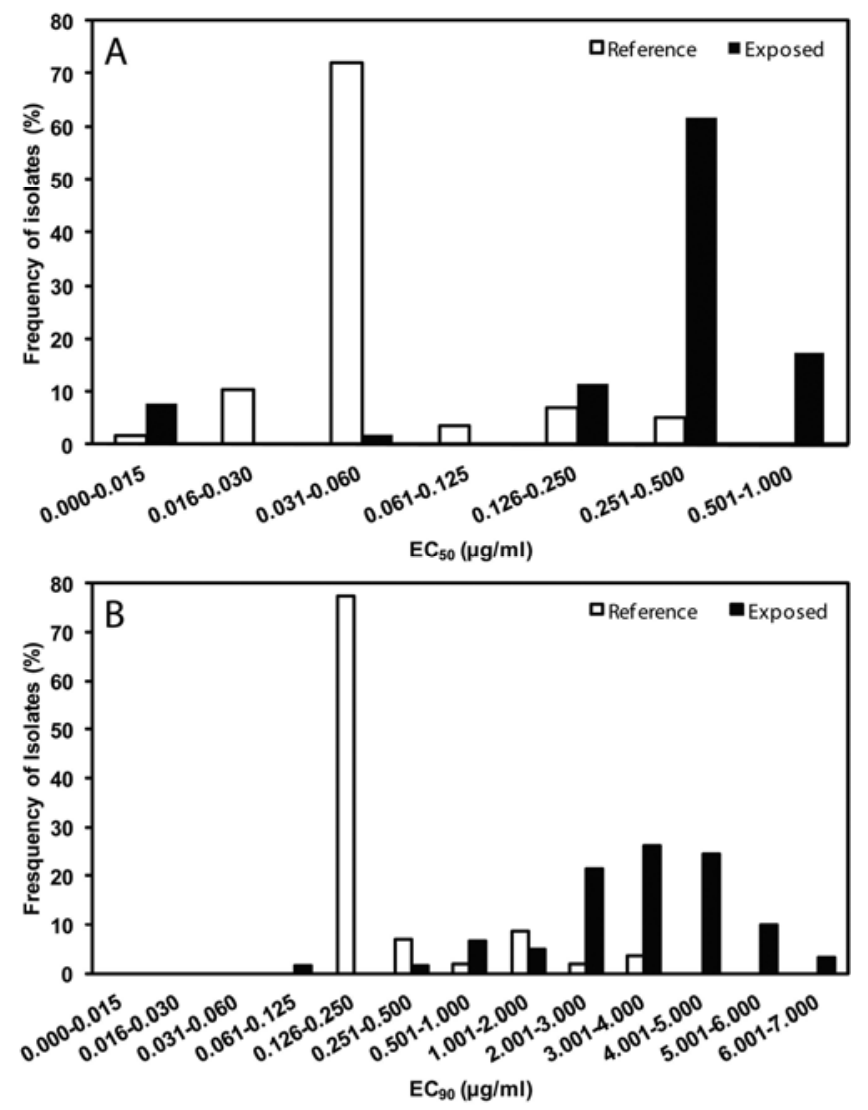

Fig. 2. Frequency distributions of mean effective concentration that inhibits $A, 50 \%$ of mycelial growth $\left(E_{50}\right)$ and $B, 90 \%$ of mycelial growth $\left(E_{90}\right)$ values to propiconazole for 57 isolates of a reference population (sensitive isolates) of Geotrichum candidum collected from different substrates prior to and during 2006 (white bars) and 61 isolates of an exposed population collected from propiconazoletreated cull fruit from 2007 to 2009 (black bars).

Table 4. Stability of sensitivity to propiconazole of six sensitive and five less-sensitive isolates of Geotrichum candidum ${ }^{\mathrm{a}}$

\begin{tabular}{lcc}
\hline & \multicolumn{2}{c}{ Transfer times } \\
\cline { 2 - 3 } Isolates & T0 & T10 \\
\hline Sensitive & $0.040 \pm 0.002$ & $0.036 \pm 0.002$ \\
Less-sensitive & $0.419 \pm 0.017$ & $0.400 \pm 0.012$ \\
\hline
\end{tabular}

${ }^{a}$ Represents the average mean effective concentration that inhibits $50 \%$ of mycelial growth $\left(\mathrm{EC}_{50}\right)$ value for the six sensitive isolates $(n=12)$ or five less-sensitive isolates $(n=10)$ from two independent experiments \pm standard error. Initial values (T0) and values after 10 transfers (T10) are presented. $\mathrm{T} 0$ and $\mathrm{T} 10 \mathrm{EC}_{50}$ values for each isolate were not significantly different $(P>0.05)$.

Table 3. Incidence of sour rot and other various pathogens on decayed cull peach and nectarine fruit collected from a packinghouse representing four distinct orchards $(n=$ sample size $)$

\begin{tabular}{lcccc}
\hline Orchard & $\begin{array}{c}\text { Sour rot } \\
\text { (Geotrichum candidum) }\end{array}$ & $\begin{array}{c}\text { Brown rot } \\
\text { (Monilinia fructicola) }\end{array}$ & $\begin{array}{c}\text { Gray mold } \\
\text { (Botrytis cinerea) }\end{array}$ & $\begin{array}{c}\text { Rhizopus and Gilbertella rots } \\
\text { (Rhizopus stolonifer or Gilbertella persicaria) }\end{array}$ \\
\hline 1 & $26.1 \pm 2.3(n=18)$ & $10.7 \pm 1.4(n=18)$ & $0.8 \pm 0.3(n=18)$ & $7.3 \pm 1.0(n=18)$ \\
2 & $4.3 \pm 1.1(n=14)$ & $6.0 \pm 1.0(n=14)$ & $0.5 \pm 0.3(n=14)$ & $0.5 \pm 0.3(n=14)$ \\
3 & $3.4 \pm 1.0(n=16)$ & $2.8 \pm 0.8(n=16)$ & $1.0 \pm 0.9(n=16)$ & $0.3 \pm 0.3(n=16)$ \\
4 & $6.4 \pm 1.5(n=13)$ & $8.1 \pm 2.0(n=13)$ & $2.4 \pm 0.6(n=13)$ & $4.9 \pm 2.1(n=13)$ \\
\hline
\end{tabular}




\section{Discussion}

Previous studies have shown how culled plant material can be a source of inoculum and provide foci for epidemic development. In addition, infected plant material can introduce new diseases and mating types of pathogens, and provide a source of fungicide-resistant strains into production fields $(9,12,14,23,24,43)$. The present study suggests that the practice of returning culled fruit to orchards has the potential to compromise sour rot disease management in California peach and nectarine orchards. The results illustrate that sour rot development can be greater on fungicide-treated, culled fruit than on fruit collected from the same orchards but not treated with the fungicide. Direct evidence is presented for a shift toward reduced sensitivity to propiconazole in $G$. candidum populations collected from culled fruit with a history of exposure to this fungicide. Thus, not only can culled fruit provide a source of inoculum for the disease, they have the potential to carry strains of G. candidum with reduced sensitivity to the fungicide.

An earlier study showed that the incidence of sour rot in peach was greater after fruit were waxed and treated with fungicides than when fruit were not waxed but only hydrocooled (36). The same study reported that fruit treated with the fungicides 2,6-dichloro-4nitroaniline and benomyl had more sour rot than untreated and unwaxed fruit. This difference in sour rot incidence was attributed to the selective action of these fungicides against competing decaycausing organisms such as $R$. stolonifer and M. fructicola (36). This may explain, in part, why in the present study fruit treated with wax and fungicide and culled during packing developed more sour rot than fruit that were not treated with wax and fungicides.

Other factors also may contribute to postharvest development of sour rot in peach and nectarine. Preconditioning (pre-ripening) is a practice widely used by packinghouses and growers in California to improve the quality of fruit shipped to distant markets $(1,11)$. Preconditioning of fruit reduces internal breakdown, a physiologi-

A

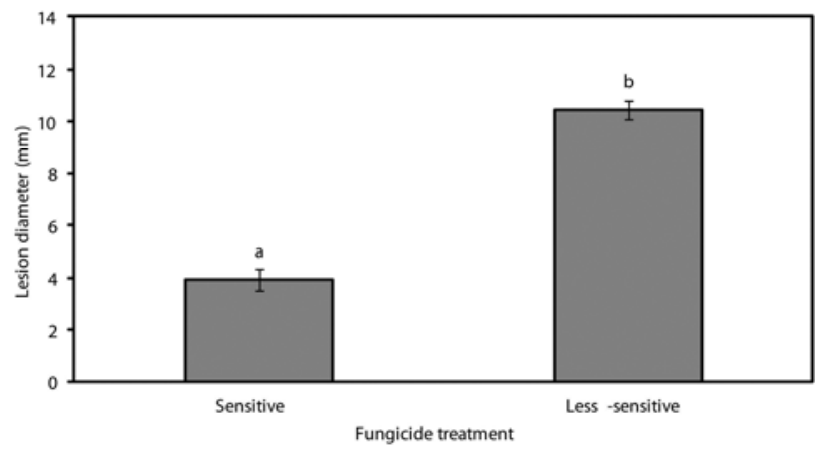

B

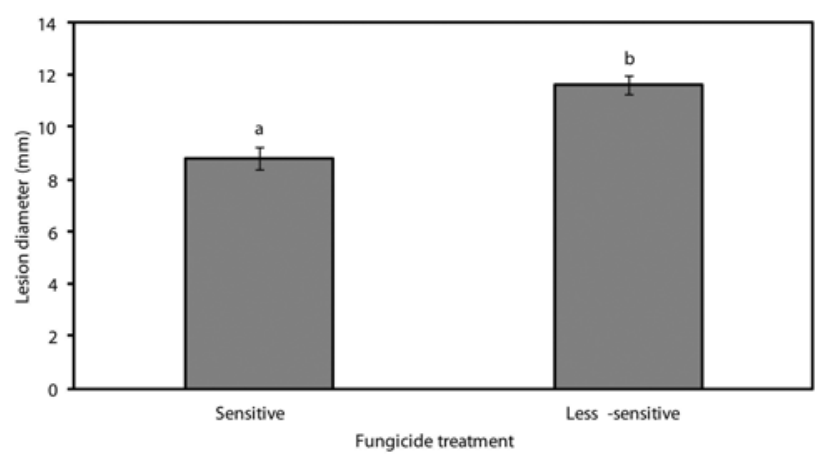

Fig. 3. Diameter of decay lesion of wound-inoculated nectarine ('Summer Fire') and peach ('Ryan Sun') fruit with a sensitive isolate (mean effective concentration that inhibits $50 \%$ of mycelial growth $\left.\left[\mathrm{EC}_{50}\right]=0.03\right)$ or a less-sensitive isolate $\left(\mathrm{EC}_{50}=\right.$ 0.47) of Geotrichum candidum. Fruit were inoculated with the pathogen either A, before or B, after treatment with propiconazole at $135 \mu \mathrm{g} / \mathrm{ml}$. cal disorder that results from chilling injury. Preconditioning involves subjecting the fruit to a 48 -h storage period at $20^{\circ} \mathrm{C}$ and high relative humidity ( $>95 \%)$ prior to cold temperature storage at $0^{\circ} \mathrm{C}$ (11). In addition, the recent practice of harvesting tree-ripened stone fruit instead of mature fruit may contribute to increased levels of sour rot. Senescent and tree-ripened fruit generally are very susceptible to most decay pathogens, and laboratory treatments that block wound healing or lead to fruit senescence increase the incidence of fruit decay (1). Preconditioned peach and nectarine are closer to senescence and, thus, are more susceptible to G. candidum and other fungal pathogens.

Sour rot incidence was as high as $26 \%$ of the culled fruit from packinghouses (Table 2). Therefore, disposal of culled fruit in orchards may introduce $G$. candidum into fields where the pathogen has not been detected. Such fruit also may provide a rich inoculum source of other major postharvest pathogens. Sporulation of $G$. candidum was observed on about $30 \%$ of the culled fruit returned to and disposed of in orchards, particularly those crushed by tractors or those that fell into irrigation trenches (data not shown). Sporulation on such damaged fruit could provide inoculum for adjacent orchards carried by insects or soil dust (7; unpublished data). This is also supported by a study on brown rot demonstrating the importance and significance of thinned nectarine fruit as a source of inoculum of $M$. fructicola when the fruit are left in the orchard and in irrigation trenches (23). Culled peach and nectarine fruit also are prone to develop other diseases such as Rhizopus rot, gray mold, and brown rot (Table 2).

Comparison of the sensitivities of the isolates collected from the culled, propiconazole-treated fruit to the reference population revealed a clear shift toward reduced sensitivity to propiconazole. Although only $14 \%$ of the isolates in the reference population had $\mathrm{EC}_{50}$ values over $0.125 \mu \mathrm{g} / \mathrm{ml}, 90 \%$ of the isolates obtained from the culled, propiconazole-treated fruit had $\mathrm{EC}_{50}$ values above this dose. The shift in sensitivity is further illustrated with the latter population, where $85 \%$ of these isolates had an $\mathrm{EC}_{90}$ over $2 \mu \mathrm{g} / \mathrm{ml}$. Thus, these isolates would be expected to grow on medium amended with propiconazole at $2 \mu \mathrm{g} / \mathrm{ml}$. The maximum residue limits for propiconazole for stone fruit are $2 \mu \mathrm{g} / \mathrm{g}$ (EPA) or $1 \mu \mathrm{g} / \mathrm{g}$ (Codex Alimentarius Commission International), suggesting that, as a general rule, residues on fruit should not exceed $1 \mu \mathrm{g} / \mathrm{g}$ (3). However, the concentration of fungicide is expected to be considerably higher than $2 \mu \mathrm{g} / \mathrm{g}$ on the fruit surface, because residue levels are determined on the basis of whole-fruit analyses. Thus, even with the shift toward reduced sensitivity observed in this study, propiconazole at current accepted label rates would be expected to continue to protect fruit against infection by G. candidum.

The presence of less-sensitive isolates within the reference populations could be because propiconazole has been registered

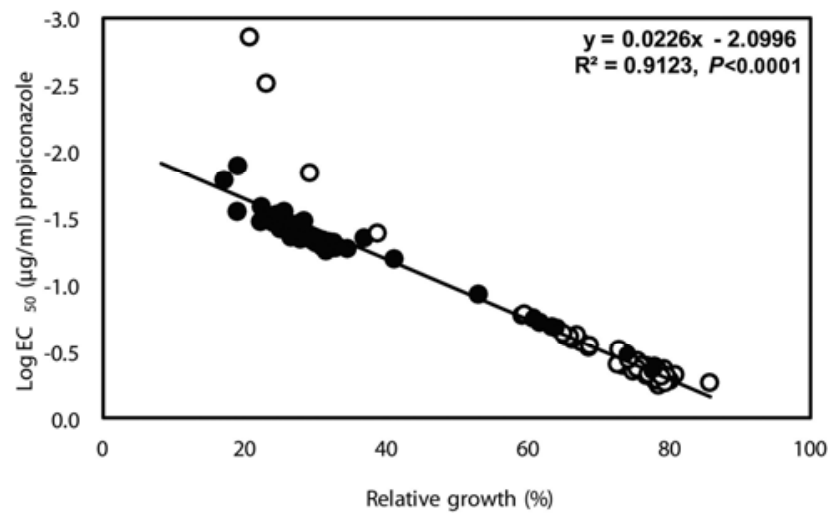

Fig. 4. Regression analysis between percent relative growth and calculated mean effective concentration that inhibits $50 \%$ of mycelial growth $\left(\mathrm{EC}_{50}\right)$ values of 57 reference $(\bullet)$ and 61 less-sensitive $(\bigcirc)$ isolates of Geotrichum candidum at a discriminatory dose of propiconazole at $0.1 \mu \mathrm{g} / \mathrm{ml}$. 
and used as a preharvest treatment against brown rot of peach and nectarine in California since 1996 (19). When fungicides are applied to control diseases, selection pressure can increase the frequency of less-sensitive strains that are naturally present among wild field populations (20). Propiconazole sprays applied to control brown rot may inadvertently select for less-sensitive strains of G. candidum present on decaying fruit. Thus, less-sensitive isolates associated with soil, debris, and decayed fruit can be introduced to contaminate processing equipment at packinghouses.

The curative action of propiconazole has been reported in a study by Cochran et al. (8), in which the fungicide prevented sour rot on tomato when it was applied up to $6 \mathrm{~h}$ after inoculation. In the current study, propiconazole-sensitive and -less-sensitive isolates were compared for their ability to cause disease in peach and nectarine fruit treated with fungicide before and after inoculation. The sensitive isolate caused significantly smaller lesions than the less-sensitive isolate regardless of when the fungicide was applied, although it was less effective when applied as a curative application on inoculated fruit. In contrast, propiconazole applied as preventive or curative applications did not have any effect on disease development in fruit inoculated with the less-sensitive isolate. Fruit treated $18 \mathrm{~h}$ after infection had larger lesions than fruit treated prior to inoculation (Fig. 3). It has been reported that propiconazole has no protective effect against some pathogens, such as Venturia inaequalis and Colletotrichum cereale $(34,37)$. Our results are similar to those reported for the effect of triazoles on mycelial growth and disease caused by M. fructicola on peach fruit (22). Protective and curative applications of triazoles, including propiconazole, prevented brown rot caused by a sensitive isolate, whereas similar propiconazole applications were not as effective against the disease caused by an isolate that was less sensitive to triazoles.

Propiconazole's efficacy as a postharvest treatment for sour rot management resulted in a Section 18 registration for use in California peach and nectarine beginning in 2006 (2). Propiconazole also significantly reduced the incidence of sour rot on citrus fruit inoculated with $G$. citri-aurantii (25). Alternative chemicals, including strobilurin fungicides, potassium sorbate with food additives, and chlorine, were ineffective either in in vitro tests with the pathogen or against sour rot development in fruit $(4,28,32,33)$. Propiconazole was found to be highly toxic in vitro to isolates of $G$. candidum causing sour rot on tomato, with $\mathrm{EC}_{50}$ values for the isolates tested between 0.01 and $0.05 \mu \mathrm{g} / \mathrm{ml}(8)$. By comparison, approximately $77 \%$ of the reference population isolates in the present study have $\mathrm{EC}_{50}$ values between 0.01 and $0.05 \mu \mathrm{g} / \mathrm{ml}$.

The discriminatory dose is an important tool to monitor shifts in fungicide sensitivity in pathogen populations, providing a threshold to differentiate sensitive and less sensitive or resistant isolates of a pathogen (30). Russell (30) defines a resistant isolate as "one with growth of $50 \%$ or more in the presence of fungicide" at the discriminatory dose. For the purposes of the present study, 0.1 $\mu \mathrm{g} / \mathrm{ml}$ was established to differentiate between the reference and exposed populations of G. candidum. However, to establish a discriminatory dose that differentiates between baseline (i.e., never exposed to propiconazole) and resistant isolates associated with a control failure, a more comprehensive analysis of field isolates will be needed. For example, a discriminatory dose of $0.3 \mu \mathrm{g} / \mathrm{ml}$ was established to monitor resistance to propiconazole of $M$. fructicola, which was 10 -fold greater than that of the baseline population $(10,42)$.

This is the first report of reduced sensitivity to propiconazole in G. candidum in natural populations occurring in a postharvest setting. However, propiconazole resistance has been reported in other pathosystems $(10,18,22,31,42)$. Nonetheless, propiconazole remains an effective chemical for control of sour rot in California, because there are no reports yet of disease management failure under current usage practices. Evaluation of more G. candidum strains isolated directly from the field, packing lines, and culled fruit will be helpful to assess the level of fungicide sensitivity to guide resistance management strategies. Under our laboratory conditions, the reduced sensitivity to propiconazole for stone fruit isolates of $G$. candidum remained stable over multiple generations following removal of selection. This, together with the similar virulence of the sensitive and less-sensitive isolates in inoculated fruit, suggests that exposed populations emerging under orchard conditions could prove to be stable. This contrasts with reports on other stone fruit pathogens for which propiconazole insensitivity was unstable (10).

There remain questions about the life cycle of the sour rot pathogen in the field. For instance, does mating occur and, if so, does mating contribute to variability in the pathogen population? Are the less-sensitive strains confined only to the packinghouses or are they present in the field, and at what levels? What is the genetic basis for the reduced sensitivity to propiconazole observed in $G$. candidum? Are less-sensitive strains as fit in the orchard soil as the sensitive strains? In spite of these gaps in our knowledge of this pathosystem, an integrated management program should include proper handling of culled stone fruit to reduce the risk of introducing fungicide-resistant strains of G. candidum. Burying the culled fruit or disposing them far from orchards should be implemented by packinghouse operators and growers. In addition, proper sanitation practices in the packinghouse, such as clean wash water and conveyer belts, should help reduce sour rot incidence in harvested fruit.

\section{Acknowledgments}

We thank C. Crisosto for his liaison with industry partners and the California Tree Fruit Agreement for financial support of this project.

\section{Literature Cited}

1. Adaskaveg, J. E., and Crisosto, C. H. 2006. Sour rot control. Central Valley Postharvest Newsl. 15(2):2-5.

2. Adaskaveg, J. E., Förster, H., Driever, G., and Crisosto, C. H. 2006. Scholar's Mentor gets an emergency registration to help manage sour rot of stone fruit in California. Central Valley Postharvest Newsl. 15(4):2-5.

3. Adaskaveg, J. E., Förster, H., Driever, G., and Crisosto, C. H. 2007. Update on Mentor 45WP-a "new tool" for postharvest management of sour rot of stone fruit in the 2007 season. Central Valley Postharvest Newsl. 16:1-4.

4. Bartz, J. A., Eayre, C. G., Mahovic, M. J., Concelmo, D. E., Brecht, J. K., and Sargent, S. A. 2001. Chlorine concentration and the inoculation of tomato fruit in packinghouse dump tanks. Plant Dis. 85:885-889.

5. Burton, C. L., and Wright, W. R. 1969. Sour rot of peaches on the market. Plant Dis. Rep. 53:580-582.

6. Butler, E. E. 1960. Pathogenicity and taxonomy of Geotrichum candidum. Phytopathology 50:665-672.

7. Butler, E. E., and Bracker, C. E. 1963. Role Of Drosophila melanogaster in epiphytology of Geotrichum, Rhhizopus, and other fruit rots of tomato. Phytopathology 53:1016-1020.

8. Cochran, A., Adaskaveg, J., and Forster, H. 2009. Propiconazole and fludioxonil for managing postharvest fungal decays of fresh market tomato. (Abstr.) Phytopathology 99:S23.

9. Couch, B. C., and Kohn, L. M. 2000. Clonal spread of Sclerotium cepivorum in onion production with evidence of past recombination events. Phytopathology 90:514-521.

10. Cox, K. D., Bryson, P. K., and Schnabel, G. 2007. Instability of propiconazole resistance and fitness in Monilinia fructicola. Phytopathology 97:448453.

11. Crisosto, C. H., Garner, D., Andris, H. L., and Day, K. R. 2004. Controlled delayed cooling extends peach market life. HortTechnology 14:99-104.

12. Davidse, L. C., Danial, D. L., and Vanwesten, C. J. 1983. Resistance to metalaxyl in Phytophthora infestance in the Netherlands. Neth. J. Plant Pathol. 89:1-20.

13. Domsch, D. H., Gams, W., and Andersson, T. H. 1980. Compendium of Soil Fungi, Volume 1. Academic Press, London.

14. du Toit, L. J., Derie, M. L., and Pelter, G. Q. 2004. Prevalence of Botrytis spp. in onion seed crops in the Columbia basin of Washington. Plant Dis. 88:1061-1068.

15. Eckert, J. W., and Ogawa, J. M. 1988. The chemical control of postharvest diseases: deciduous fruits, berries, vegetables and root tuber crops. Annu. Rev. Phytopathol. 26:433-469.

16. Förster, H., and Adaskaveg, J. E. 1999. Fludioxonil, a new reduced risk postharvest fungicide for management of fungal decays of stone fruit. (Abstr.) Phytopathology 89:S26.

17. Förster, H., Driever, G. F., Thompson, D. C., and Adaskaveg, J. E. 2007. Postharvest decay management for stone fruit crops in California using the "reduced-risk" fungicides fludioxonil and fenhexamid. Plant Dis. 91:209215.

18. Fungicide. 2009. FRAC List of Plant Pathogenic Organisms Resistant to 
Disease Control Agents. Crop Life, Brussels.

19. Gianessi, L. P., and Silvers, C. S., eds. 2000. Trends in Crop Pesticide Use: Comparing 1992 and 1997. National Center for Food and Agricultural Policy, Washington, DC.

20. Gisi, U., Chin, K. M., Knapova, G., Farber, R. K., Mohr, U., Parisi, S., Sierotzki, H., and Steinfeld, U. 2000. Recent developments in elucidating modes of resistance to phenylamide, DMI and strobilurin fungicides. Crop Prot. 19:863-872.

21. Harvey, J. M., Smith, W. L., and Kaufman, J., eds. 1972. Market diseases of stone fruits: cherries, peaches, nectarines, apricots, and plums. Agricultural Handbook 414. United States Department of Agriculture, Washington, DC

22. Holb, I. J., and Schnabel, G. 2007. Differential effect of triazoles on mycelial growth and disease measurements of Monilinia fructicola isolates with reduced sensitivity to DMI fungicides. Crop Prot. 26:753-759.

23. Hong, C. X., Holtz, B. A., Morgan, D. P., and Michailides, T. J. 1997. Significance of thinned fruit as a source of the secondary inoculum of Monilinia fructicola in California nectarine orchards. Plant Dis. 81:519-524.

24. Lamour, K. H., and Hausbeck, M. K. 2001. Investigating the spatiotemporal genetic structure of Phytophthora capsici in Michigan. Phytopathology 91:973-980.

25. McKay, A. H., Forster, H., and Adaskaveg, J. E. 2007. Sensitivity of isolates of Geotrichum citri-aurantii, the causal pathogen of sour rot in citrus, to DMI fungicides. (Abstr.) Phytopathology 97:S74.

26. Michailides, T. J., Morgan, D. P., and Day, K. R. 2004. First report of sour rot of California peaches and nectarines caused by yeasts. Plant Dis. $88: 222$.

27. Michailides, T. J., and Spotts, R. A. 1990. Transmission of Mucor piriformis propagules to fruit of Prunus persica by Carpophilus spp. and Drosophila melanogaster. Plant Dis. 74:287-291.

28. Palou, L., Smilanick, J. L., and Crisosto, C. H. 2009. Evaluation of food additives as alternative or complementary chemicals to conventional fungicides for the control of major postharvest diseases of stone fruit. J. Food Prot. 72:1037-1046.

29. Putman, A. I., Jung, G., and Kaminski, J. E. 2010. Geographic distribution of fungicide-Insensitive Sclerotinia homoeocarpa isolates from golf courses in the northeastern United States. Plant Dis. 94:186-195.

30. Russell, P. E., ed. 2004. Sensitivity baselines in fungicide resistance research and management. FRAC Monogr. No. 3. Crop Life International, Brussels.
31. Schnabel, G., Bryson, P. K., Bridges, W. C., and Brannen, P. M. 2004. Reduced sensitivity in Monilinia fructicola to propiconazole in Georgia and implications for disease management. Plant Dis. 88:1000-1004.

32. Schnabel, G., Chai, W., and Cox, K. D. 2006. Identifying and characterizing summer diseases on 'Babygold' peach in South Carolina. Plant Health Progress. doi:10.1094/PHP-2006-0301-01-RS

33. Smilanick, J. L., Aiyabei, J., Gabler, F. M., Doctor, J., Sorenson, D., and Mackey, B. 2002. Quantification of the toxicity of aqueous chlorine to spores of Penicillium digitatum and Geotrichum citri-aurantii. Plant Dis. 86:509-514.

34. Szkolnik, M. 1981. Physical modes of action of sterol-inhibiting fungicides against apple diseases. Plant Dis. 65:981-985.

35. Wade, N. L., and Morris, S. C. 1982. Causes and control of cantaloupe postharvest wastage in Australia. Plant Dis. 66:549-552.

36. Wells, J. M. 1977. Sour rot of peaches caused by Monilinia implicata and Geotrichum candidum Phytopathology 67:404-408.

37. Wong, F. P., and Midland, S. L. 2007. Sensitivity distributions of California populations of Colletotrichum cereale to the DMI fungicides propiconazole, myclobutanil, tebuconazole, and triadimefon. Plant Dis. 91:1547-1555.

38. Wong, F. P., and Wilcox, W. F. 2002. Sensitivity to azoxystrobin among isolates of Uncinula necator: baseline distribution and relationship to myclobutanil sensitivity. Plant Dis. 86:394-404

39. Yaghmour, M. A., Bostock, R. M., Adaskaveg, J. E., Crisosto, C. H., and Michailides, T. J. 2007. Pathogenicity and inoculum sources of Geotrichum candidum causing sour rot of peaches and nectarines in California. (Abstr.) Phytopathology 97:S126.

40. Yaghmour, M. A., Bostock, R. M., Adaskaveg, J. E., and Michailides, T. J. 2009. Biology and sources of inoculum of Geotrichum candidum causing sour rot of peaches and nectarines in California. (Abstr.) Phytopathology 99:S145.

41. Yaghmour, M. A., Bostock, R. M., and Michailides, T. J. 2012. Biology and sources of inoculum of Geotrichum candidum causing sour rot of peach and nectarine fruit in California. Plant Dis. 96:204-210.

42. Zehr, E. I., Luszcz, L. A., Olien, W. C., Newall, W. C., and Toler, J. E. 1999. Reduced sensitivity in Monilinia fructicola to propiconazole following prolonged exposure in peach orchards. Plant Dis. 83:913-916.

43. Zwankhuizen, M. J., Govers, F., and Zadoks, J. C. 1998. Development of potato late blight epidemics: disease foci, disease gradients, and infection sources. Phytopathology 88:754-763. 